\title{
Competency Mapping of Employee with Special Reference to Unitech Plasto Components Pvt. Ltd, Chennai
}

\author{
K. B. Praveen, S. Tamilarasi
}

\begin{abstract}
The process of human resource management is to bring the organization and the employees together to achieve their goals. It is the great importance of any organization. In simple word competency mapping play a vital role in the selecting, recruiting and retaining the right person to the right job. The research is mainly focused on the communication skill with gender in the employee's competency towards in organization. The tool of research is $U$ test and percentage analysis. The sample size of the research is 200 employees. The research done by issuing the questionnaires. The result I founded in this research Competency is the main tool in the organizational because by this the employees get evaluated by their performances. To achieve more rewards and also the employee knowledge will be concluded.
\end{abstract}

Keywords: Competency mapping, Employees communication skills, Training and developing.

\section{INTRODUCTION}

\section{A. Evolution of competency}

Competency was started in 20th century. The business processes need the unique competency for the task to be performed by an individual. In the world war II implement management centric views, that the low level employees accept the work which is assigned by the officers without competency movement during 1973 when David McClelland published an article in American Psychologist this developed a new methods to know about the human performance for US information agency.

\section{B. Competency Classification}

It is broadly classified into three categories which are Organizational Competency; Job related Competency, and Personal Competency.

Organizational competence is the unique factors in the organization that makes a company very competitive. C.K. Prahlad and Hamel (1994) He wrote a book called "Competency in the future" stated that it gives information to access a wide variety of markets that makes a important contribution to perceived customers to end the product and that makes the competitor to imitate a product.

Job related competency are the competency which are need to perform a specific job.

Revised Manuscript Received on December 05, 2019.

* Correspondence Author

K. B. Praveen*, Research Scholar, Department of Commerce, Faculty of Science \& Humanities, SRMIST, Kattankulathur, Chennai, India.

Dr. S. Tamilarasi, Associate Professor, Department of Commerce, Faculty of Science \& Humanities, SRMIST, Kattankulathur, Chennai, India. asking any question on them, The turning point for

Job related competency is important criteria for the Human Resource functions which are Selection, Training and Development, Performance appraisal, Compensation etc..,Personal Competency is the competency of individual that make a individuals to perform their tasks within the organization. It included the various level of behavioral competencies apart from the knowledge and skill levels of an individual persons.

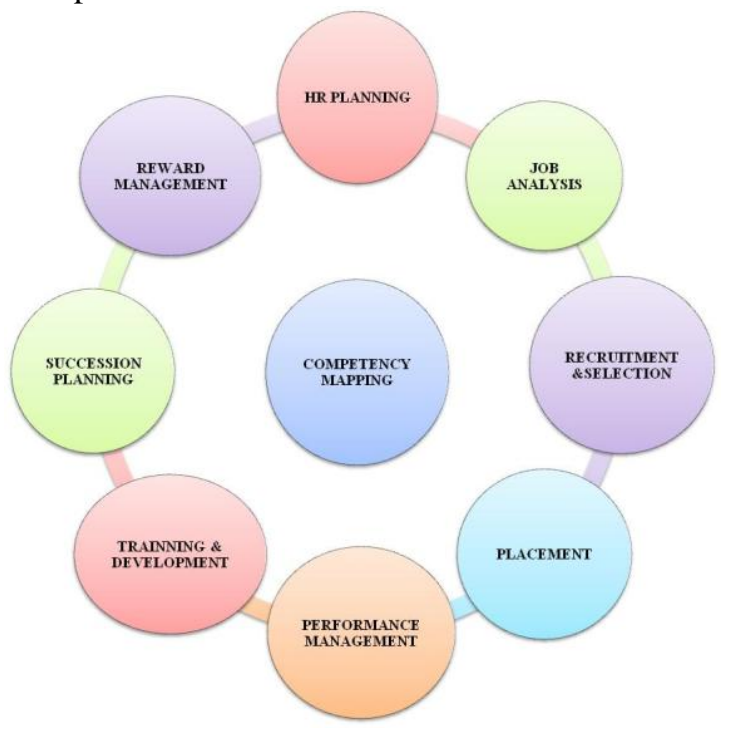

Figure - 1: Process of Competency

\section{Competency Mapping}

The process of human resource management is to bring the organization and the employees together to achieve their goals. It is the great importance of any organization. In simple word competency mapping play a vital role in the selecting, recruiting and retaining the right person to the right job. The competency create a particular position to be mapped an accurate job of profile is created. The broad categories in the competency are Generic and Managerial. Apart from the recruiting and selection process it brings the inherent strength and weakness of employee and help them to develop themselves. It is the greater tool the Organization. In this ways competency mapping is helps to attain the goals in the organization with the help of employees.

\section{REVIEW LITERATURE}

Solomon (2013) stated that they try to explore their level of competency prevailing among the executives of public sectors. But the study shows that they have a moderate satisfaction level of managerial and general competency.

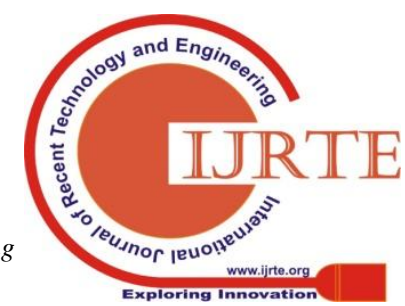


Md.Ishtiak uddin et. al. (2012) quoted that competency mapping is the important tool to the organization. The tools are Job analysis, Job description, Competency matrix Job specification, 360 appraisal feedback etc.., In his view the competency mapping are used to train their employees in the succession planning.

Gasper (2012) Stated that competency is the process of selection and performance management. Selection is the healthy and structured manner. The candidates are before enter into the organization they need to give some demonstration by that they evaluate the employees. Performance management is evaluating the further training and development need for the employees with may lead the HR executives assists promotions and transfers.

Yuvaraj(2011) focused that job competency it is one the classification of competencies. They explained that knowledge, skills, abilities and attitudes in the organization and the work in the organization. GAP analysis is also using in some extends.

Y. Nagaraju and V.Sathyanarayanan gowda(2009) Stated that competency mapping is the Advance organizational practices tool to illustrate the employees tasks in the organization. It is the valuable tool of human capital and for its developments.

Su-Chin Hsieh,Jui-Shin Lin,Hung-Chun Lee(2002) analyzed and proved that competency mapping improve the job performance. It helps to manage the stress on expansion and the working term of competency.

\section{RESEARCH METHODOLOGY}

\section{A. Objectives}

- To identify knowledge, Communication skills and attitude level of employee towards organizational competency

- To analyze the methods to bridge the gap between existing and expected level of competency from the employee

\section{B. Source of the Study}

For this study primary data plays a major role for this research by using the questionnaire. For some refers we used secondary data also.

\section{Tools and Techniques}

Statistical tools like percentages and Mann-Whitney U test, which is used as a device to analyze and interpret the competency mapping of employee.

\section{Sample Size}

Convenience sampling was used for the survey.200 Employees were selected as sample. The questionnaires were distributed to the respondents in the selected sample.

\section{E. Limitation of the Study}

- There is no physical groundwork to prove the response given is a true measure of the suggestion of all the employee

- Time was the major constraint in collection of data.

\section{ANALYSIS AND INTREPRETATION}

Table - 1: Profile of the Respondents

\begin{tabular}{|c|c|c|}
\hline $\begin{array}{c}\text { Socio Economic Profile of the } \\
\text { Respondents }\end{array}$ & Frequency & $\begin{array}{c}\text { Percentage } \\
\text { (\%) }\end{array}$ \\
\hline Gender & & \\
\hline Male & 101 & 50.5 \\
\hline Female & 99 & 49.5 \\
\hline Age (In Years) & & \\
\hline $20-28$ & 117 & 58.5 \\
\hline $29-38$ & 59 & 29.5 \\
\hline $39-48$ & 4 & 2.0 \\
\hline above 48 & 20 & 10.0 \\
\hline Qualification & & \\
\hline Diploma & 143 & 7105 \\
\hline UG & 36 & 18.0 \\
\hline PG & 14 & 7.0 \\
\hline Others & 7 & 3.5 \\
\hline Experience & & \\
\hline 3-5 years & 92 & 46.0 \\
\hline 6-8 years & 97 & 48.5 \\
\hline Above 9 years & 11 & 5.5 \\
\hline
\end{tabular}

\section{Source: Primary Data}

The above table shows that socio economic profile of the Competency Mapping of Employee It is clearly understood that Competency Mapping of Employee in industry are high in Male category on gender as 101.For the age category of 208-28 Years with 117 employees. Out of 200 employees 143 employees completed their education in Diploma. 97 employees are in experience of 6-8 years.

Table - 2: Mann Whitney $U$ test for significant difference between Mean Rank of Gender with respect to Employee communication skills towards organizational competency

\begin{tabular}{|l|c|c|c|c|}
\hline $\begin{array}{c}\text { Employee } \\
\text { communication skills } \\
\text { towards organizational } \\
\text { competency }\end{array}$ & \multicolumn{2}{|c|}{$\begin{array}{c}\text { Mean rank for } \\
\text { Gender }\end{array}$} & \multirow{2}{Z}{$\begin{array}{l}\text { Z } \\
\text { value }\end{array}$} & P value \\
\cline { 2 - 4 } & Male & Female & & \\
\hline $\begin{array}{l}\text { Listening skills: Listen to } \\
\text { others views with } \\
\text { patience }\end{array}$ & 86.44 & 114.85 & 3.766 & 0.000 \\
\hline $\begin{array}{l}\text { Precision } \\
\text { communication : Listen } \\
\text { to others and express the } \\
\text { ideas with clarity and } \\
\text { precision }\end{array}$ & 78.59 & 122.85 & 5.531 & $.000 *$ \\
\hline $\begin{array}{l}\text { Persuasiveness : Able to } \\
\text { move other in getting } \\
\text { things done }\end{array}$ & 94.38 & 101.76 & 1.426 & 0.146 \\
\hline $\begin{array}{l}\text { Sensitivity: Aware of } \\
\text { what is going on in the } \\
\text { work place and responds } \\
\text { in a suitable manner to } \\
\text { situations as they arise }\end{array}$ & 95.21 & 105.64 & 1.321 & 0.038 \\
\hline
\end{tabular}

Source: Primary Data - Note: * denotes associate at 5\% level

Published By:

Blue Eyes Intelligence Engineering 
Since the $\mathrm{P}$ value is $<0.05$ Where $\mathrm{H} 0$ is rejected in association of the Gender and the factors of Employee communication skills towards organizational competency. Hence the data is not follows the normal distribution. if it is not follows the normal distribution then we can follow the non -parametric test.

\section{MAJOR FINDINGS}

- It is clearly understood that competency mapping are high in Male category on gender as 101

- $\quad$ For the age category of 20-28 Years with 117 employees

- Out of 200 employees 143 employees completed their education in Diploma

- 97 employees are in 6-8 years of experience.

- Since the $\mathrm{P}$ value are $<0.05$ Where $\mathrm{H} 0$ is rejected in association of the Gender and the Employee communication skills towards organizational competency.

\section{SUGGESTION}

From the about analysis and findings of study clearly epitomize in the in-depth of analysis has been conducted and all the objectives of the research work has been completed successfully. It is found the workmen are vastly experience with a high degree of competency in all aspect of production and design.

The company has to take a different variety of aspects as to improve the competency level of the employee.

\section{CONCLUSION}

I concluded that the competency mapping helps to motivate and train the employees. By giving the rewards they get motivated and that makes them to work more efficiently and to achieve their target in the business goals. Competency is the main tool in the organizational because by this the employees get evaluated by their performances. To achieve more rewards and also the employee knowledge will be concluded.

\section{REFERENCES}

1. Y. Nagaraju and V.SathyanarayanaGowda Oct Vol 3 ,2012, Isuue No.10 ISSN 0976-2183. A Study of employee competency mapping strategies at select organization of bangalore : International journal of Research in commerce and management.

2. Su-Chin Hsieh Jui-Shin Lin Hung-Chun Lee Oct ,2012 Analysis on Literature Review of Competencyinternational Review of Business and Economics Vol.2 pp

3. Gaspar Robert (2012) A Study on the Perception of Human Resource Executives On Competency Mapping for the Superior Results, International Journal of Social Science Tomorrow, Vol.1, No.8.

4. Mitrani AM.,\&FittDalziel,.Competency“ Based Human Resource Management" Hay Group 1992.

WEBSITE:

$$
\begin{array}{ll}
\text { a. } & \text { www.indianjournal.in } \\
\text { b. } & \text { www.managementparadise.com } \\
\text { c. } & \text { www.leadershipindia.com } \\
\text { d. } & \text { www.wiki.answers.com } \\
\text { e. } & \text { www.zeromillion.com }
\end{array}
$$

\section{AUTHORS PROFILE}

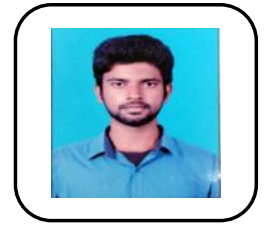

K. B. Praveen, Ph.D Research scholar, Published paper A Study on challenges and opportunities in implementing E-HRM in International conference in SRM IST kaatankulathur, Customer satisfaction on swiggy with delivery executives with special reference to Chennai city in Research Day 2019 in SRM IST kattankulathur. Serving has a President for Students of association in commerce department.

Dr. S. Tamilarasi, Associate Professor. Published in articles in International

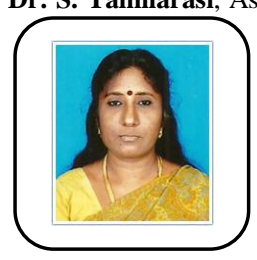
Journal of Research In Engineering, It And Social Sciences (IJREISS) - Are We Nodding For The Forensic Accounting? - An Indian Context - Oct 2018 - ISSN - 2250-0588 GST on MSME: Its Impact. $\quad-\quad 2018 \quad-\quad$ ISBN: 978-93-87756-15-1.3.International Journal of Economic Research - Exploring the Work life balance of Street Vendors with ref.to Tambaram: A Township area in Chennai city- Oct-2016-ISSN -0972-9380, IF-1.632 International Journal of Pharmaceutical Sciences Review and Research - A study on Job Satisfaction among Paramedical Sales Representatives with Ref.to Chennai City- June 2016- ISSN- 0976-044x, IF - 2.544 .International Journal of Economic and Business Review- A study on student teacher mentality towards academics with ref to undergraduate educationNov-2016, ISSN - 2349-0187, IF-6.484 International Journal of Commerce and Management Research - A Study on effect on Entrepreneurship in Economic Development -Sep 2016 - ISSN - 2321-3604, IF -3.53. 